\title{
The Archaeology of Medieval Europe. Vol. 1. Eighth to Twelfth Centuries AD edited by James Graham-Campbell with Magdalena Valor. (Aarhus University Press, 2008)
}

\section{by Michael Staunton}

This is the first of a two-volume collaborative project designed to comprise the first complete account of medieval archaeology across the continent of Europe (the second covers the twelfth to sixteenth centuries). Originating in the Fourth European Symposium for Teachers of Medieval Archaeology at Seville in 1999, the stated aim of the project is to transcend the largely nationally-based research in the field to provide students with an appreciation of the European dimension of the discipline. As a wideranging, informative and attractively-presented textbook, The Archaeology of Medieval Europe is valuable as an introduction to the discipline and a work of reference for students of both archaeology and medieval history. The contributors forty-one in all are some of the leading experts in their respective fields, drawn from all over Europe. Bookended by an Introduction, a useful chapter on Research and Teaching Now and an Afterword, the fourteen chapters in between take up such broad themes as Urban Settlement, Trade and Exchange, Religions, and Death, but contributors are also allowed to focus more narrowly on case studies in the form of box-texts: for example, a chapter on Peoples and Environments contains short inserts on Norse expansion across the North Atlantic, Central and Northern Europe as seen by Early Medieval Travellers and Geographers, and Arabs and Berbers in Al-Andalus; Housing Culture is illustrated by examples from Iceland and Spain. There are useful and well-reproduced maps, diagrams and illustrations throughout, and of particular value is the detailed bibliography appended to each chapter.

The focus on 800-1200cuts across most traditional divisions of the period, but convincing reasons are provided for this choice. By the beginning of the eighth century, advances in agricultural production were in place which facilitated the significant expansion in urban life and commerce which followed, and the latter trends were well established by 1200. Conversion to Christianity was widespread across Europe by the beginning of the period, and with it an end to the practice of clothed burial. And the year 800 marked the establishment of the Empire in the west with the coronation of Charlemagne, which had lasting resonances for the idea of Europe. While this period is most readily associated with advances in towns, trade and communications, the rural and agrarian character of life continued to dominate. This is addressed in the early chapters on Peoples and Environments and Rural Settlement, where the archaeological record is particularly important to our understanding of the issues. The chapters on Urban Settlement, Travel and Transport, and Trade and Exchange in particular address what has often been regarded as a revolutionary period in economic and social life. The authors here tend 
to reject both the notion of a sharp break with the Roman world and a subsequent commercial revolution in favour of a more evolutionary interpretation. While, as noted, medieval archaeology is no longer seen as primarily ancillary to medieval history, there is much here that plays into current debates in the latter discipline. For example, the evidence of feasting and hospitality, and symbols of power, offer a different perspective to the written documents which form the usual basis of the study of courtliness and ritual. But, the material record has its own lacunae: as noted, the most common form of travel and transport on human feet - has left virtually no record.

If periodization is one area where this book takes an idiosyncratic approach, another is its emphasis on a European-wide perspective, and here the results are more mixed. Most writers point to regional variation across Europe, and many lament the lack of trans-national or even trans-regional coordination of research projects, but there is little consistency of approach to this European perspective. The chapters on Food, and on Trade and Exchange, divide their analyses between Mediterranean and northern Europe; that on Urban Settlement examines western Europe on the one hand and central, northern, eastern and southern Europe on the other. Others are divided chronologically or thematically with less attention to regional variation. The emphasis on the European theme is stronger in some chapters than in others. In a discussion of Material Culture and Daily Life it is argued that the expansion of the Empire eastwards resulted in increasingly unified standards among certain social classes, identified as a type of Europeanisation. More difficult to accept are the claims in the Afterword that Frederick Barbarossa was a veritable European successor to Charlemagne or that by 1200 the Europeanisation of Europe was well under way, especially when the concepts of Europe and Europeanisation are not fully developed and indeed are largely neglected by most contributors. It could be argued that the different needs of each subject required a divergence in approach, but the lack of consistency across the book suggests that this is less by design than as a consequence of the difficulties of standardizing the work of over forty contributors. Some chapters notably that on Rural Settlement - address the issues surrounding periodization while most do not; some, such as those on Fortifications, and Church Buildings, pay more attention to issues around current scholarship than others. Even the box-texts, advertised as one of the key features of the book, do not appear in every chapter. This can be confusing for the reader, and makes the book a less coherent synthesis than it aspires to be. But if it does not quite achieve its more ambitious overall aims, this is nonetheless a book which succeeds well in its individual parts, and which will be read with profit by those interested in medieval archaeology and history alike.

Dr Michael Staunton is a lecturer in medieval history at University College Dublin and is currently Government of Ireland Senior Fellow in the Arts and Humanities and Visiting Medieval Fellow at Fordham University. 